\title{
The Influence of Digital Literacy and Entrepreneurial Behavior on Small Business Performance (Study on Culinary Business in Jeneponto Regency)
}

\author{
Nur Samsul Bahri*, Muhammad Rakib, Muh. Ihsan Said, Rahmatullah, \& Muhammad Hasan ${ }^{5}$ \\ Department of Economic Education, Faculty of Economics and Business, Universitas Negeri Makassar, Indonesia
}

\begin{abstract}
Using Jeneponto Regency's culinary businesses as a case study, this study tries to investigate whether digital literacy and entrepreneurial behavior have an impact on business performance. Business performance is the dependent variable in this study. The independent factors in this study include digital literacy and entrepreneurial behavior. Using quantitative descriptive research and correlational methods, this study examines the relationship between the two variables. 307 culinary enterprises registered with the Jeneponto Regency Department of Cooperatives and SMEs comprised the study's population, from which a sample of 39 culinary firms was selected. Observing, documenting, and distributing questionnaires were used to collect data (questionnaires). Descriptive statistical analysis and inferential statistics are employed in the analysis process. Digital Literacy (X1) and Entrepreneurial Behavior (X2) had a good and significant effect on the success of small enterprises (Y) in culinary businesses in Jeneponto Regency, according to the study results. Because of its greater regression coefficient value than digital literacy, entrepreneurial activity is the most influential variable in this study.
\end{abstract}

Keywords: Digital Literacy, Entrepreneurial Behaviour, Business Performance

\section{Introduction}

Kemakmuran ekonomi suatu negara sangat bergantung pada keberhasilan usaha kecil dan menengah (UKM). Perluasan UKM diharapkan dapat memperluas fondasi ekonomi kerakyatan dan memberikan kontribusi yang signifikan bagi peningkatan perekonomian Indonesia. Sektor UKM terbukti kuat dalam menghadapi krisis moneter beberapa tahun terakhir. Dengan bukti ini, jelas bahwa UKM akan dipertimbangkan dalam meningkatkan daya saing pasar dan menstabilkan pengaturan keuangan dan hadir sebagai jawaban atas ekonomi nasional yang sehat.

Menurut (Farmawaty et al., 2018), kinerja ditentukan oleh hasil kerja dan perilaku kerja. Jika kinerja bergantung pada hasil, yang dilihat adalah jumlah kualitas dan kuantitas yang dihasilkan, namun jika dilihat dari perilaku kerja, yang dinilai adalah bagaimana karyawan memenuhi komitmen mereka dan berkontribusi secara positif atau negatif terhadap pemenuhan tujuan organisasi yang diukur ketika mengevaluasi kinerja berdasarkan perilaku kerja. Kinerja individu atau kelompok diartikan sebagai kesediaan untuk melaksanakan suatu kegiatan dan melaksanakannya sesuai dengan komitmen dan hasil yang diharapkan. Oleh karena itu, kemampuan seseorang untuk berprestasi sangat dipengaruhi oleh tiga faktor: keterampilan dan keinginan, serta lingkungan. Untuk itu, seseorang harus memiliki keinginan yang besar untuk mempelajari dan memahami aspek-aspek yang mempengaruhi profesinya agar dapat memberikan kinerja yang jujur. Kinerja yang baik tidak akan tercapai sampai hal-hal yang mempengaruhinya dipahami.

Internet dengan segala kecanggihannya telah mengurangi hambatan geografis dalam berkomunikasi dan mengakses informasi. Melalui jaringan juga, suatu informasi dapat menyebar lebih cepat dan lebih luas dari media sebelumnya. Penerapan teknologi digital dalam bisnis, seperti dalam pemasaran produk dan jasa, juga sangat menguntungkan.

\footnotetext{
* Corresponding author.

E-mail address: nursamsulb@gmail.com (Nur Samsul Bahri)
} 
Banyaknya peningkatan dalam komunitas pengguna internet Indonesia menyebabkan event digital marketing juga semakin meningkat dan kebiasaan masyarakat yang beragam. Akibatnya, pebisnis memanfaatkannya saat menjual produk atau layanan mereka. Instagram, Facebook, Twitter, dan YouTube adalah platform media sosial populer untuk pemasaran digital (Hasan et al., 2021).

Literasi digital dianggap dapat meningkatkan kinerja UKM, mempermudah bisnis dengan memungkinkan mereka menjangkau pembeli yang lebih luas di seluruh dunia. Pengusaha UKM dapat menjalankan usahanya secara lebih efisien dengan menggunakan teknologi data, dan mereka tidak memerlukan aset sebanyak bisnis lama. Dengan demikian, sebagai wirausahawan (entrepreneur) dituntut untuk siap memahami dan mengevaluasi ilmu yang diterimanya. Kemampuan mengumpulkan informasi diimbangi dengan kemampuan menelusuri dan mengenali informasi tersebut, terutama dalam bentuk digital, atau yang dikenal dengan kemampuan literasi digital (Zahro, 2019).

Menurut Paul Gilster (1997) dalam (Winarsih \& Furinawati, 2018) bahwa literasi digital adalah kapasitas untuk memahami dan memanfaatkan berbagai informasi dari perangkat digital secara efektif dan efisien dalam beragam skenario seperti akademisi, karier, dan kehidupan sehari-hari. Di dunia digital, literasi digital juga mengacu pada kapasitas seseorang untuk menggunakan teknologi digital secara efektif untuk pembuatan data, komunikasi, kolaborasi, serta pengambilan dan penilaian. Lebih lanjut, literasi digital dapat didefinisikan sebagai kemampuan manusia untuk menggunakan internet sebagai sumber pengetahuan dan sebagai media untuk mencari informasi. Alhasil, para pelaku usaha, khususnya usaha kecil, telah menetapkan literasi digital sebagai tujuan untuk mengembangkan usahanya dan perekonomian masyarakat (Zahro, 2019). Dengan demikian, kondisi ini mendorong setiap orang untuk memiliki literasi dalam penggunaan media digital. Dengan fleksibilitas menggunakan perangkat digital, seseorang dapat menjadi seorang wirausaha.

Komponen sumber daya manusia merupakan salah satu variabel terpenting dalam meningkatkan kinerja usaha kecil (wirausahawan). Ketika berbicara tentang kewirausahaan, kita berbicara tentang orang-orang dengan keterampilan komunikasi yang baik, pengetahuan kewirausahaan yang diperoleh melalui sekolah dan pelatihan, pengalaman, pendampingan, dan pola pikir wirausaha (Rakib, 2010). Kewirausahaan dapat didefinisikan sebagai keadaan pikiran dan sikap yang terus aktif atau inventif untuk meningkatkan pendapatan dalam kegiatan perusahaan. Ketika datang ke perusahaan baru dan kemungkinan komersial, seorang pengusaha harus bisa berpikir kreatif dan imajinatif. Kewirausahaan aptitude dapat didefinisikan sebagai kapasitas untuk menggabungkan kreativitas, inovasi, antusiasme, dan kepercayaan diri untuk mengambil risiko untuk menangkap peluang.

Perilaku wirausaha juga dianggap sebagai salah satu variabel terpenting dalam keberhasilan atau kinerja bisnis seorang wirausaha. Efektivitas komunikasi, pembelajaran kewirausahaan, dan sikap kewirausahaan memainkan peran utama dalam kinerja usaha kecil (Rakib, 2012). Proses kewirausahaan berkisar pada perilaku kewirausahaan (Khalid et al., 2016). Menurut Musyadar \& Gumilar (2019), wirausahawan yang sukses adalah seseorang yang dapat mengintegrasikan nilai, kualitas utama (pola sikap), dan perilaku dengan ketersediaan informasi, pengalaman, dan kemampuan praktis. Perilaku kewirausahaan, yang didefinisikan sebagai pengetahuan, sikap, dan keterampilan, merupakan integrasi jangka panjang antara pengetahuan dan sikap mental. Dengan begitu, seorang wirausahawan dapat menopang kelangsungan usahanya dengan memiliki perilaku wirausaha yang baik, begitu pula sebaliknya (Aina dalam Prabawati \& Susanti, 2019).

UMKM merupakan sektor usaha yang mendominasi di Indonesia. Di Indonesia terdapat 56 juta usaha kecil dan menengah. Usaha kuliner merupakan salah satu bentuk usaha kecil yang sedang berkembang. Kekuatan masa depan Indonesia diprediksi akan muncul dari ekonomi kreatif pada tahun 2025. Industri kreatif menyumbang 7,38 persen dari produk domestik bruto pada tahun 2015 dari total aset sistem keuangan atau senilai Rp852 triliun dengan sektor kuliner memberikan kontribusi terbesar terhadap PDB (Badan Ekonomi Kreatif, 2017).

Kabupaten Jeneponto memiliki usaha kuliner dari jenis usaha yang ada. Pelaku usaha tersebar di 11 kecamatan di Kabupaten Jeneponto. Usaha kuliner merupakan salah satu unit UKM yang menjadi salah satu penggerak roda perekonomian, tidak terkecuali Kabupaten Jeneponto. Pada tahun 2019, Dinas Koperasi dan UKM Kabupaten Jeneponto mencatat sebanyak 307 UKM di bidang kuliner yang tersebar di seluruh kabupaten. Hal tersebut menunjukkan bahwa UKM memainkan peran penting dalam pembangunan ekonomi Kabupaten Jeneponto. 
Berdasarkan uraian tersebut, peneliti ingin melihat Pengaruh Literasi Digital Dan Perilaku Kewirausahaan Terhadap Kinerja Usaha Kecil (Studi Pada Usaha Kuliner Di Kabupaten Jeneponto)”.

\section{Methods}

Penelitian kuantitatif menggunakan analisis data statistik deskriptif dan statistik inferensial (analisis regresi linear berganda) untuk menggambarkan fenomena secara numerik. Pada penelitian ini teknik pengumpulan datanya menggunakan angket (kuesioner) dengan analisis instrument penelitian menggunakan uji validitas dan uji reabilitas, karena materi akan disajikan dalam bentuk angka-angka yang dapat dinilai secara statistik. Pada penelitian ini, peneliti menggunakan teknik korelasional, yang melibatkan pengujian hubungan antara dua variabel, khususnya seberapa besar fluktuasi satu variabel terkait dengan variabel lainnya. Variabel bebas adalah variabel yang mempengaruhi variabel terikat (dependen). Variabel bebas penelitian ini meliputi literasi digital (X1) dan perilaku kewirausahaan (X2) sedangkan varaibel terikat dalam penelitian ini adalah kinerja usaha (Y). Variabel bebas yang mempengaruhi variabel terikat, dan variabel bebas yang mempengaruhi variabel terikat. Dimana sistem ini dapat digunakan sebagai metode penghitungan jumlah sampel terkecil. Sebagai hasil dari penerapan rumus Slovin pada sampel, jumlah sampel dalam penelitian ini adalah 39. Mengamati (observing), mendokumentasikan, dan menyebarkan kuesioner adalah beberapa pendekatan pengumpulan data yang digunakan.

\section{Results and Discussion}

Setiap variabel yang diteliti dalam penelitian ini memiliki item pernyataan yang valid, yang ditunjukkan oleh hasil uji validasi. Banyak item pernyataan dengan tanda bintang atau item pernyataan >0,3160 memiliki nilai Pearson Correlation yang tinggi. Berdasarkan hasil uji reliabilitas instrumen penelitian yang menunjukkan cronbach's alpha > 0,600, secara umum instrumen penelitian yang digunakan dalam penelitian ini memiliki tingkat konsistensi jawaban responden yang dapat dipercaya (Table 1).

Table 1. Hasil Uji Reliabilitas

\begin{tabular}{lccc}
\hline Variabel & Cronbach Alpha & r-kritis & Kriteria \\
\hline Literasi Digital & 0,849 & 0,600 & Reliabel \\
Perilaku Kewirausahaan & 0,768 & 0,600 & Reliabel \\
Kinerja Usaha & 0,808 & 0,600 & Reliabel
\end{tabular}

Sumber: Hasil Olah Data Angket, 2021

\subsection{Uji Normalitas}

Untuk mengevaluasi apakah kumpulan data normal, pengujian ini harus dilakukan pada data tersebut. Tes Kolmogorov-Smirnov satu sampel digunakan untuk menentukan hasil tes ini. Tes sampel tunggal dapat digunakan untuk menilai apakah sesuatu itu benar atau tidak berdasarkan hasil sampel. Nilai apa pun yang kurang dari 0,05 menunjukkan distribusi data yang tidak normal ketika variabel Asymp.Sig (2-tailed) digunakan. Ada signifikansi asimtotik sebesar 0,200 0,05 menggunakan uji ini. Dengan demikian, dapat dikatakan model regresi telah memenuhi kriteria normal berdasarkan temuan (Table 2).

Table 2. Hasil Uji Normalitas

\begin{tabular}{lccc}
\hline Variabel & Asymp.Sig & Signifikansi & Kriteria \\
\hline Literasi Digital & 0,713 & 0,05 & Normal \\
Perilaku Kewirausahaan & 0,637 & 0,05 & Normal \\
Kinerja Usaha & 0,630 & 0,05 & Normal \\
\hline
\end{tabular}

Sumber: Hasil Olah Data Angket, 2021 


\subsection{Uji Linearitas}

Pengujian ini berfungsi guna menentukan spesifikasi model pada studi ini benar. Jika perbedaan signifikan dari linieritas > dari signifikasinya 0,05 , data dikatakan linier. Terdapat variasi 0,164 dari linearitas antara literasi digital dan kinerja bisnis dalam hasil perhitungan. Selain itu, perilaku kewirausahaan memiliki dampak 0,660 terhadap kinerja perusahaan. Penyimpangan signifikan dari linearitas adalah 0,164. Ada juga 0,000 sebagai linearitas signifikansi dengan $\mathrm{p}<0,05$ sebagai aturan. Berlandaskan penalaran ini, maka hubungan antara literasi digital (X1) dan perilaku kewirausahaan (X2) dan kinerja usaha (Y) adalah linear, artinya hubungan antara keduanya adalah positif (Table 3).

Table 3. Hasil Uji Linearitas

\begin{tabular}{|c|c|c|c|c|}
\hline Variabel & Deviation from Linearity & Linearity Signifikan & Taraf Signifikansi & Keterangan \\
\hline $\begin{array}{l}\text { Literasi Digital Terhadap Kinerja } \\
\text { Usaha }\end{array}$ & 0,096 & 0,000 & 0,05 & Linear \\
\hline $\begin{array}{l}\text { Perilaku Kewirausahaan Terhadap } \\
\text { Kinerja Usaha }\end{array}$ & 0,660 & 0,000 & 0,05 & Linear \\
\hline
\end{tabular}

Sumber: Hasil Olah Data Angket, 2021

\subsection{Uji Regresi Linear Berganda}

Analisis regresi digunakan dalam penelitian ini untuk menguji pengaruh masing-masing variabel literasi digital (X1) dan variabel perilaku kewirausahaan di Kabupaten Jeneponto terhadap kinerja usaha (Y). Berdasarkan perhitungan SPSS 21, hal tersebut dapat diamati pada Table 4.

Table 4. Hasil Analisis Linear Berganda

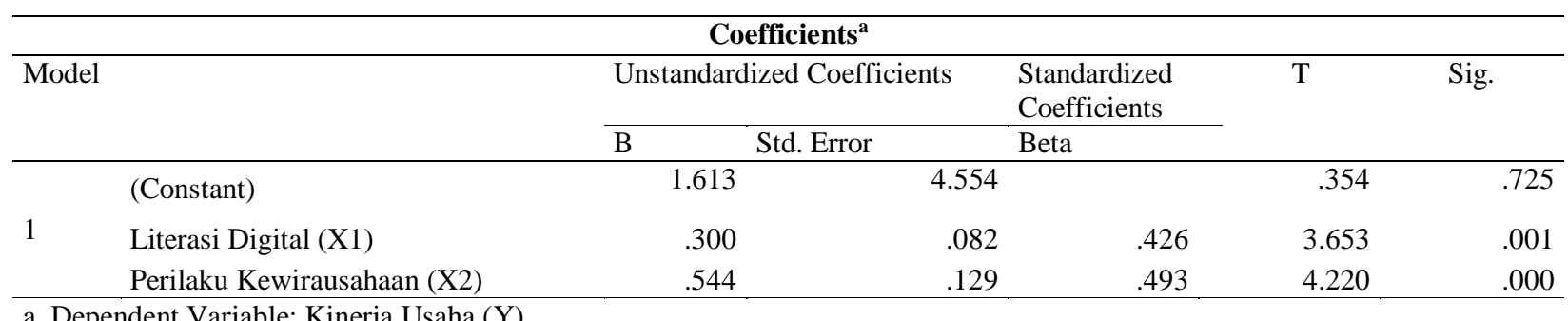

a. Dependent Variable: Kinerja Usaha (Y)

Sumber: Hasil Olah Data Angket, 2021

Seperti yang terlihat pada tabel 4, nilai konstanta adalah 1,613, dan koefisien X1;0,300 dan X2; 0,544, sehingga menghasilkan persamaan berikut jika diterapkan dalam persamaan regresinya:

$$
\mathrm{Y}=1,613+0,300 \mathrm{X} 1+0,544 \mathrm{X} 2
$$

\subsection{Uji Koefisien Korelasi $(R)$}

Analisis korelasi adalah semacam pengukuran statistik yang sering digunakan dalam pengolahan data. Metode statistik korelasi sering digunakan dalam pengolahan data. Jika Anda memiliki setidaknya dua variabel, Anda dapat menggunakan korelasi sebagai alat statistik. Hubungan antara variabel independen dan variabel dependen dapat ditentukan dengan menggunakan metode ini. Koefisien $\mathrm{R}$, memiliki rentang nilai 0 hingga 1, menggambarkan kekuatan hubungan antara variabel endogen dengan eksogen dengan skor yang lebih dekat ke 1 menunjukkan hubungan yang lebih kuat dan nilai yang lebih dekat ke 0 menunjukkan hubungan yang lebih lemah. Hasil uji koefisien korelasi dapat di lihat pada tabel berikut: 
Table 5. Uji Koefisien Korelasi (R)

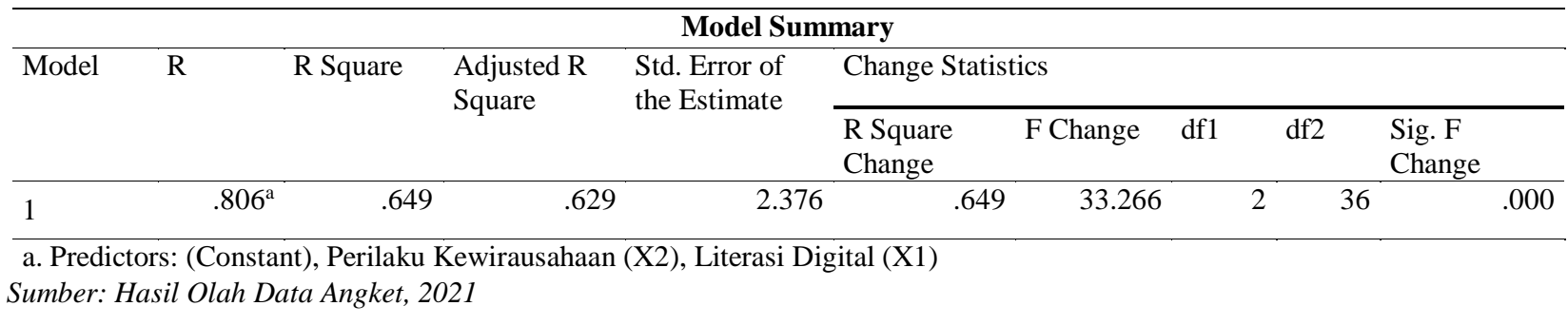

Tabel 5 menunjukkan bahwa nilai Sig. Perubahan F sebesar 0,000 0,05 yang menunjukkan bahwa data tersebut saling berkorelasi. Dalam hal ini, koefisien korelasi (R) adalah 0,801-0,00 (sangat kuat). Sehingga, terdapat hubungan yang substansial antara variabel Literasi Digital (X1) dengan Perilaku Kewirausahaan (X2) serta variabel Kinerja Usaha (Y) masing-masing sebesar 0,806 persen atau 80,6 persen. Hubungan positif (searah) antara literasi digital dan perilaku kewirausahaan dan kinerja usaha dapat disimpulkan dari nilai koefisien korelasi.

\subsection{Uji Koefisien Determinasi $\left(R^{2}\right)$}

Koefisien determinasi menunjukkan besarnya kontribusi variabel independen terhadap variabel dependen. Koefisien determinasi adalah ukuran seberapa baik variabel dapat dijelaskan oleh variabel independen. Hal ini bermanfaat untuk memiliki koefisien korelasi yang tinggi. Koefisien determinasi dapat berkisar dari 0 hingga 1 besarnya. Nilai $\mathrm{R}^{2}$ yang rendah menunjukkan bahwa variabel independen memiliki kemampuan yang terbatas untuk menjelaskan variabilitas variabel dependen. Nilai $\mathbf{R}^{2}$ yang rendah menunjukkan bahwa variabel independen memiliki potensi yang terbatas untuk menjelaskan variabilitas.. Jika nilai $\mathrm{R}^{2}$ rendah, maka variabel bebas terbatas untuk menjelaskan variabel tersebut. Perhatikan output rangkuman model dari temuan analisis regresi pada tabel 5. Tabel ini menunjukkan bahwa nilai determinasi $\left(\mathrm{R}^{2}\right)$ adalah 0,649 persen, artinya Literasi Digital dan Perilaku Kewirausahaan mempengaruhi Kinerja Usaha sebesar 0,649\% atau 64,9\% dan sisanya 31,7\% dipengaruhi oleh faktor lain yang tidak diteliti dalam penelitian ini.

\subsection{Pengaruh Literasi Digital Terhadap Kinerja Usaha}

Hasil analisis menunjukkan bahwa Literasi digital memiliki dampak positif dan signifikan terhadap kinerja usaha. Literasi digital memiliki dampak yang menguntungkan pada kinerja bisnis. Hal ini menunjukkan bahwa semakin kuat literasi digital seorang wirausahawan, semakin baik kinerja usahanya.

Indikator pencarian di internet, pandu arah hypertext, evaluasi konten informasi, dan penyusunan pengetahuan semuanya digunakan dalam hipotesis variabel literasi digital. Berdasarkan hasil uji hipotesis, indikasi dengan skor tertinggi adalah indikator directional hypertext yang termasuk dalam kategori sangat tinggi dengan skor 61,54 persen. Indikator ini terdiri dari tiga pernyataan yaitu "Saya mampu memahami dengan baik setiap konten usaha yang saya dapatkan melalui internet", "Saya mengerti cara melakukan browsing dan mencari informasi yang tersebar di internet untuk mengembangkan usaha" dan "Saya dapat memahami prosedur hypertext dan hyperlink (seperti: http/www) dalam mengembangkan usaha". Artinya pengetahuan pandu arah hypertext (hypertext navihgation) dengan kemampuan memahami cara melakukan browsing dan mencari informasi, serta memahami prosedur hypertext dan hyperlink sangat berdampak pada perkembangan kinerja usaha. Indikator dengan nilai tertinggi kedua adalah internet searching dengan persentase 58,97 persen, indikator dengan nilai tertinggi ketiga adalah evaluasi konten informasi yaitu pada kategori tinggi dengan persentase 51,28 persen, dan indikator dengan skor terendah adalah penyusunan pengetahuan yang memiliki persentase 46,15 persen.

Pada variabel literasi digital, semua pernyataan yang memperoleh skor tertinggi adalah: "Saya mengerti cara menelusuri dan mencari informasi yang tersebar di internet untuk mengembangkan bisnis" dan "Saya dapat memahami prosedur hypertext dan hyperlink (seperti: http/www) dalam mengembangkan sebuah bisnis," keduanya 
memiliki nilai yang sama dan berada dalam kategori yang sama (sangat tinggi). Ini menunjukkan bahwa pelaku usaha memiliki literasi digital yang sangat baik.

Hasil pengujian menunjukkan bahwa, ditemukan dampak positif dan signifikan dari literasi digital secara parsial terhadap kinerja usaha. Temuan penelitian ini konsisten dengan temuan Hastuti, (2020) \& Santoso dkk., (2019). Menurut hasil penelitiannya, keberhasilan usaha kecil dipengaruhi secara positif dan signifikan oleh literasi digital..

\subsection{Pengaruh Perilaku Kewirausahaan Terhadap Kinerja Usaha}

Hasil analisis menunjukkan bahwa perilaku kewirausahaan memiliki dampak positif dan signifikan terhadap kinerja usaha. Hal ini menggambarkan bahwa semakin tinggi sikap inovatif, keberanian mengambil resiko, dan semakin tekun dalam bekerja wirausahawan, maka semakin baik kinerja usahanya.

Hipotesis variabel perilaku kewirausahaan menggunakan indikator inovatif, berani mengambil risiko, dan tekun berusaha. Berdasarkan hasil uji hipotesis, indikator dengan skor tertinggi adalah indikator tekun berusaha dengan total 89,74 persen. Indikator ini terdiri dari tiga pernyataan: "Keinginan yang kuat adalah aspek terpenting dalam memulai bisnis", "Kerja keras adalah kunci terpenting keberhasilan bisnis", dan "Pengalaman membantu dalam manajemen bisnis". Dengan demikian, dapat diartikan bahwa dengan adanya kemauan kuat yang diiringi dengan kerjas keras serta didukung oleh pengalaman yang dimiliki sangat berdampak pada kinerja usaha. Dengan persentase sebesar 61,54 persen, indikator tertinggi kedua adalah inovatif yang berada pada kategori sangat tinggi. Indikator perilaku kewirausahaan terendah adalah indikator berani mengambil risiko, yaitu berada pada kategori tinggi dengan persentase 48,72 persen.

Menurut hasil pengisian kuesioner "Kerja keras adalah kunci utama kesuksesan bisnis" dinilai sebagai "Sangat Tinggi" untuk semua pernyataan perilaku kewirausahaan. Hal ini menunjukkan bahwa untuk meningkatkan kinerja bisnis, diperlukan kerja keras, karena kerja keras adalah kunci keberhasilan bisnis.

Hasil pengujian menunjukkan bahwa secara parsial perilaku kewirausahaan berpengaruh positif dan signifikan terhadap kinerja usaha. Temuan penelitian ini sejalan dengan temuan Puspitasari, (2013), Putri et al., (2017) \& Aprilia, (2019). Menurut temuannya, secara parsial perilaku kewirausahaan berpengaruh positif dan signifikan terhadap Kinerja Usaha.

\subsection{Kinerja Usaha Kecil Kuliner Kabupaten Jeneponto}

Pengujian hipotesis menunjukkan bahwa usaha kecil di Kabupaten Jeneponto memiliki kinerja yang sangat baik. Hal ini diukur dengan tiga indikator: peningkatan pendapatan, perluasan wilayah pemasaran, dan peningkatan volume penjualan. Berdasarkan hasil uji hipotesis, indikator perluasan wilayah pemasaran dengan persentase 74,36 persen memiliki skor tertinggi. Indikator ini terdiri dari tiga pernyataan: "Membangun hubungan yang solid dengan mitra bisnis untuk mempromosikan bisnis", "Melakukan pengembangan produk untuk memperluas wilayah pemasaran", dan "Melakukan pemasaran online untuk menjangkau khalayak yang lebih besar." Sehingga, dapat diartikan bahwa membangun hubungan baik dengan mitra bisnis dan dengan adanya usaha pengembangan produk dalam rangka peningkatan daerah pemasaran serta dengan adanya pemasaran online melalui teknologi digital akan memperluas wilayah pemasaran dan pada akhirnya sangat berdampak pada peningkatan kinerja usaha. Indikator peningkatan volume penjualan merupakan indikator terbesar kedua, dengan persentase 54,61 persen, sedangkan peningkatan pendapatan terendah, dengan persentase 48,72 persen.

Hasil rata-rata tanggapan responden terhadap setiap item pernyataan tentang variabel kinerja usaha menunjukkan bahwa usaha kecil kuliner di Kabupaten Jeneponto memilki kinerja yang sangat baik. Hal ini ditunjukkan dengan keyakinan pelaku usaha yang sangat tinggi dalam memandang peningkatan pendapatan usaha, peningkatan volume penjualan, serta memperluas wilayah pemasaran terhadap usaha yang dimilikinya. 


\subsection{Pengaruh Literasi Digital dan Perilaku Kewirausahaan Secara Bersama-Sama Terhadap Kinerja Usaha}

Berdasarkan hasil penelitian hipotesis ini, kedua variabel memiliki pengaruh yang positif dan signifikan terhadap kinerja usaha pada usaha kuliner Kabupaten Jeneponto. Temuan ini menyiratkan bahwa jika faktor literasi digital dan perilaku kewirausahaan meningkat, kinerja bisnis juga akan meningkat.

Nilai F yang ditentukan sebesar 33.266 berdasarkan perhitungan data, nilai F tabel sebesar 3,26 menunjukkan bahwa F hitung > F tabel. Nilai 0,000 kurang signifikan dari nilai $=0,05$. Hal ini menunjukkan bahwa H0 ditolak dan H1 diterima. Sehingga, dapat dikatakan bahwa literasi digital dan perilaku kewirausahaan memiliki dampak positif dan signifikan terhadap kinerja bisnis secara simultan atau bersama-sama.

Nilai koefisien determinasi (adjusted $R$ Square) sebesar 0,649 atau 64,9 persen. Hal ini berarti 64,9\% variasi kinerja usaha yang bisa dijelaskan oleh variasi variabel independen yaitu literasi digital dan perilaku kewirausahaan. Sedangkan sisanya sebesar $35,1 \%$ dipengaruhi oleh vaiabel-variabel lain diluar dari model regresi dalam penelitian ini.

Temuan penelitian ini mendukung teori Puspitasari, (2013) bahwa untuk mencapai tujuan perusahaannya, wirausahawan terlibat dalam perilaku wirausaha, yang meliputi ketepatan dalam mengidentifikasi kemungkinan bisnis, keberanian mengambil risiko dan mengembangkan produk inovatif serta mampu bersaing di pasar dalam berupaya mencapai kinerja yang lebih baik. Eisanhardt \& Martin dalam (Hastuti, 2020) juga mengemukakan teori bahwa kinerja UKM yang sangat baik disebabkan oleh faktor sumber daya. Sumber daya tersebut meliputi aset, pengetahuan literasi digital dan keterampilan orientasi kewirausahaan.

\section{Conclusions}

Secara parsial terdapat pengaruh yang positif dan signifikan antara literasi digital dan perilaku kewirausahaan terhadap kinerja usaha kecil pada usaha kuliner di Kabupaten Jeneponto dilihat dari indikator variabel literasi digital yang meliputi pencarian di internet (internet searching), pandu arah hypertext (hypertextual navigation), evaluasi konten informasi (content evaluation) dan penyusunan pengetahuan (knowledge assembly) dan indikator variabel perilaku kewirausahaan yaitu inovatif, berani mengambil resiko, dan tekun berusaha. Dan secara simultan literasi digital dan perilaku kewirausahaan berpengaruh positif dan signifikan terhadap kinerja usaha kecil pada usaha kuliner di Kabupaten Jeneponto.

Seperti yang telah dijelaskan, literasi digital dan perilaku wirausaha merupakan salah satu faktor penting dalam keberhasilan sebuah usaha. Untuk itu, pelaku usaha perlu membuka wawasan dan memiliki pengetahuan tentang literasi digital dan memiliki perilaku kewirausahaan yang baik sehingga dapat meningkatkan kinerja usahanya. Dan diharapkan peneliti selanjutnya dapat mengembangkan penelitian ini dengan meneliti variabel-variabel lain yang akan mempengaruhi kinerja usaha. Peneliti selanjutnya dapat menggunakan metode lain dalam mengkaji kinerja usaha, misalnya melalui wawancara mendalam dengan pelaku usaha, agar data yang diperoleh lebih variatif dibandingkan dengan kuesioner yang sudah tersedia jawabannya.

\section{References}

Aprilia, R. (2019). Pengaruh Literasi Informasi Dan Perilaku Kewirausahaan Terhadap Kinerja Usaha Kecil Studi Pada Usaha Kuliner Di Kota Makassar. Skripsi. Fakultas Ekonomi Universitas Negeri Makassar.

Badan Ekonomi Kreatif. (2017). Bekraf Outlook. Retrieved from Bekraf: (Diakses 05 September 2020 pukul 13.45 WITA) www.bekraf.go.id.

Farmawaty, E., Ramli, A., \& Rahmatullah. (2018). Faktor Faktor Yang Mempengaruhi Kinerja Guru Ekonomi Pada Sma Negeri Di Kota Makassar. Jurnal Ekonomi Dan Pendidikan (Jekpend), 1(2), 23-29. Https://Doi.Org/10.22216/Benefita.V3i2.2061 
Hasan, M., Dzakiyyah, A., Kumalasari, D. A., Safira, N., \& Aini, S. N. (2021). Transformasi Digital UMKM Sektor Kuliner Di Kelurahan Jatinegara, Jakarta Timur. Jurnal Bisnis \& Kewirausahaan, 17(2), 1-15.

Hastuti, W. K. (2020). Pengaruh Pengetahuan Literasi Digital Dan Orientasi Kewirausahaan Terhadap Kinerja Usaha Mikro Kecil Dan Menengah (UMKM) Batik Di Surakarta. Skripsi. Fakultas Keguruan Dan Ilmu Pendidikan Universitas Sebelas Maret, Surakarta.

Khalid, B., Maalu, J., Gathungu, J., \& Mccormick, D. (2016). Entrepreneurial Behaviour, Institutional Context And Performance Of Micro And Small Livestock Enterprises In North Eastern Region Of Kenya. Global Journal Of Management And Business Research: A Administration And Management, 16(9), 47-53.

Musyadar, A., \& Gumilar, I. (2019). Konsep Dan Proses Kewirausahaan. Kewirausahaan. Edisi 3. Agribinis Bidang Minat Penyuluhan Dan Komunikasi Perikanan., 1-28.

Prabawati, S., \& Susanti. (2019). Pengaruh Efikasi Diri, Pendidikan Kewirausahaan, Literasi Keuangan, Dan Literasi Digital Terhadap Perilaku Berwirausaha Siswa Smk Negeri 10 Surabaya. Journal Pendidikan Akuntansi, 07(01), 64-76.

Puspitasari. (2013). Pengaruh Perilaku Kewirausahaan Petani Anggrek Terhadap Kinerja Usaha: Kasus Di Kecamatan Gunung Sindur Dan Parung, Kabupaten Bogor, Dan Kecamatan Serpong, Kota Tangerang Selatan.

Putri, R. A., Cepriadi, \& Yulida, R. (2017). Pengaruh Perilaku Wirausaha Terhadap Kinerja Peternak Ayam Broiler Pola Kemitraan (Contract Farming) Di Kota Pekanbaru. Jurnal Sungkai, 5(2), 1-15.

Rakib, M. (2010). Pengaruh Model Komunikasi Wirausaha, Pembelajaran Wirausaha, Dan Sikap Kewirausahaan Terhadap Kinerja Usaha Kecil. Jurnal Ilmu Pendidikan, 17(2), 121-129.

Rakib, M. (2012). Analisis Faktor-Faktor Yang Mempengaruhi Kinerja Usaha Kecil Di Kota Pare-Pare (Pp. $984-$ 993).

Santoso, H., Abdinagoro, S. B., \& Arief, M. (2019). The Role Of Creative Self-Efficacy, Transformational Leadership, And Digital Literacy In Supporting Performance Through Innovative Work Behavior: Evidence From Telecommunications Industry. Management Science Letters, 9, 2305-2314. Https://Doi.Org/10.5267/J.Ms1.2019.7.024

Winarsih, E., \& Furinawati, Y. (2018). Literasi Teknologi Dan Literasi Digital Untuk Menumbuhkan Keterampilan Berwirausaha Bagi Kelompok Pemuda Di Kota Madiun. Prosiding Seminar Nasional \& Internasional, 1(1), 23-29.

Zahro, E. K. (2019). Kemampuan Literasi Digital Untuk Meningkatkan Keuntungan Usaha Pada Kalangan Pelaku Usaha Skala Kecil Di Kota Surabaya. Jurnal Universitas Airlangga. 